\title{
Contemporary administrative division and historically shaped regional borders: a comparative analysis in Poland
}

\author{
Wojciech Janicki* \\ Maria Curie-Sklodowska University, Poland
}

The administrative division of Poland changed several times over centuries, and the last decades witnessed a few significant border shifts. Socio-economic or political criteria usually created the foundations of proposed new administrative division, while historical criteria were generally ignored. The author postulates that borders' historical durability itself should be evaluated higher than it was to date, because it supports the creation of objective regions, provides political stability and reinforces the formation of regional identity. The basis for the analysis was the overlapping of 21 maps showing the external borders of Poland and the borders of administrative units of the first order between 990 and 2020. The map-based comparison has revealed that a surprisingly high share of present borders follows former borders. This provides strong support to the postulate of ceasing further changes in Poland's administrative division and border changes.

Key Words: administrative division, regional borders, durability of borders, objective regions, historical regions.

Article Info: Received: April 3, 2020; Revised: May 13, 2020; Accepted: May 15, 2020; Online: May 23, 2020

\footnotetext{
" Correspondence address

Address: Institute of Socioeconomic Geography and Spatial Management, Maria CurieSklodowska University, al. Krasnicka 2d, 20-718 Lublin, Poland.

Phone: +48 815376825 | Email: wojciech.janicki@umcs.pl

(C)2020 Human Geographies; The authors

(9) $\stackrel{\omega}{r}$ This work is licensed under a

Creative Commons Attribution 4.0 International License. DOI:10.5719/hgeo.2020.141.3
} 


\section{Introduction}

In October 2019 a parliamentary election was held in Poland. The Law and Justice party (PiS) won for the second time in a row. The party attaches great importance to the implementation of its election promises and remains convinced that this will ensure its re-election. One of the still unrealised promises made by PiS before the 2015 election was the change of the administrative division of Poland. It has not yet become the main subject of public debate due to the much higher rank of other changes in the general public perception. However, the slogans well-known for many years of separating Warsaw from the Mazowieckie Voivodship and establishing the Central Pomeranian Voivodship appeared again in the public space before the 2019 election, when a month before the election Jarosław Kaczyński, the PiS chairman, proclaimed once again the exclusion of Warsaw from Mazowieckie Voivodship. These are clear signals that further steps in this direction and a further change, or at least a severe correction of the administrative division of Poland, can be expected. The absolute majority of 235 out of a total of 460 MPs allows PiS to carry out all those political changes in Poland which require an ordinary majority in the lower chamber of parliament. The upper house of parliament, where PiS failed to secure a majority, can only delay parliament's decisions for a short period of time.

Throughout history, Poland's administrative division has changed many times. Even in the relatively short period of the Polish statehood, after the end of the World War II, there were as many as five major changes in the number and course of the borders of administrative units of the 1st order (voivodships), even if we do not take into account the less important changes. To date, research and scientific work on the borders of voivodships have focused mainly on justifying the rationality or irrationality of the administrative division in force at a given moment, and on presenting the advantages and disadvantages of potential new solutions. Preliminary information on the planned change in the territorial organisation of the state has always led to an avalanche of new works, the authors of which aimed at proposing a new, as rational as possible, administrative division. These works sometimes, especially in the period before 1989, were created in response to the needs of national decision-making centres and, as a result, they often failed to avoid being involved in current politics.

The perspective of the next, upcoming changes in the administrative division in Poland requires a thorough examination of the extent to which the new changes are justified on the grounds of a calm, non-politically motivated and rational analysis. The main aim of this paper is to analyse the course of borders of historical regions in Poland throughout its history and to see to what extent the current course of borders of voivodships overlap their former courses. This formulation of the objective is guided by the conviction that one of the features of well-delineated regions is given by their historically well-established durability. Therefore, if it turns out that the convergence of the borders of the current administrative division and the course of historical borders is low, then the argument of a historical nature in favour of defending the current administrative 
division fails. If, however, the convergence is high, the opponents of introducing further changes will gain substantive support in the discussion, which will probably take place on a political level.

The work in which the issue analysed in this paper will be addressed has never been done in Poland before (see and compare Sobczyński, 1984; Janicki \& Łucjan 2009). Also on a global scale, such works are unique. For many years, researchers have been concentrating mainly on analyses of external borders, which is a traditional subject of political geographical research, on conditions of crossborder cooperation, regionalisation or decentralisation (Minghi, 1963; Elazar, 1999; Taylor and Flint, 2000; Yoder, 2003; Jones et al., 2004; Lunden, 2004; Kolossov, 2005; Cox et al., 2008). The works concerning the analysis of the course of internal administrative borders are much less numerous, and most often they concern the legitimacy of delimitation in a specific way, usually concerning natural variables (Sng et al., 2018). The only work concerning changes in the course of internal administrative borders that has been identified is MartíHenneberg's paper (2005), in which he presents a series of maps showing the evolution of administrative boundaries in Central and Western Europe between 1850 and 2000. However, this work focuses mainly on a brief analysis of the factors that determined the high level of stability of Intermediate Level Administrative Units in most Western European countries and the low level in Eastern Europe, rather than on the persistence of specific border fragments in any of the countries analysed.

In this paper, the temporal scope covers the period from 990 to 2020 . Therefore it fills a significant gap in the spatial analysis of the border course and seems to provide a good conceptual foundation for further, perhaps even more detailed, work for the same or other areas. The methodology developed in the paper may be used to analyse both the durability of unit borders at various levels of administration and to indicate the borders of objective regions in other countries as well.

\section{Literature review}

The analysis of the borders of historical regions in Poland requires a working definition of the subject of the study, i.e. the region. The literature on this issue is vast, therefore it is not possible to analyse it in detail in this paper. It does not seem to be purposeful either, so the review below is of an indicative nature only. It focuses mainly on the Polish literature on the subject, because the works of foreign authors discuss only sporadically the regional division in Poland as the subject of analysis or at least as a point of reference.

The very idea of a region was analysed by many researchers, including Dziewoński (1967), Piskozub (1987), Szul (1993), Zawadzka (1993), or Jałowiecki (1996a, 1996b). The most interesting is undoubtedly the work by Chojnicki \& Czyż (1993), in which the authors distinguish three ways of understanding the term region. In the first approach, it is a research tool that enables the creation of 
a basis for spatial analysis and the foundation of an analytical-cognitive regionalisation. Within its framework, on the basis of various criteria, two types of regions are distinguished: homogeneous and nodal. In the second view, a region is a tool for action, whose task is to facilitate the organisation of social activities in its space. Therefore, it serves the purposes of practical regionalisation and may facilitate, for example, the decentralisation of administration. The borders of such a region should take into account the existence of a network of connections and divisions of regional systems. The third approach assumes that the region is the object of cognition, an objective entity which is the subject of a regionalisation analysis known as structural. This last perspective is interestingly developed by Dumolard (1980, p. 21), who writes that "regions exist independently of the researchers", and they have to be discovered not created.

The latter approach can easily be seen as idealistic as it is a well-established fact that changes of administrative boundaries are usually based on political reasons and that an entirely objective, independent analysis of regional entities is not possible. Nevertheless, it is worth noting that it points to some vital truths: regions created by politicians within the framework of practical (administrative) regionalisation without objectively existing spatial links or regularities will not function well until the imposition of new spatial constraints creates within them networks of new interdependencies, allowing for the efficient functioning of regions in the new realities. Chojnicki \& Czyż (1993) claim that a region should be a subject of cognition in order to be considered rational, which further strengthens the thesis that in search of optimal solutions for administrative division (practical regionalisation) one should not forget about the achievements of structural regionalisation (a region as a subject of recognition).

It should be noted that, in addition to administrative regions, there are many other types of regions. These include economic, urban, ethnocultural, linguistic, relict or historical regions (Szul, 1993). Only the latter will be considered in this work and for its purposes let us assume, after Alexandrowicz (1993), that historical regions are former administrative units of the first order. They owe their presentday distinctness from the units surrounding them to their former separateness.

\section{Study area}

After World War II there was only one significant correction of the Polish borders. In 1951, Poland exchanged with the USSR the eastern part of the then Lubelskie Voivodship near the town of Sokal for a part of the Drohobych County with the town of Ustrzyki Dolne. The areas were $480 \mathrm{sq} . \mathrm{km}$. each and the actual reason for the exchange was USSR' desire to take direct control over the hard coal deposits in the newly controlled area (Czubiński \& Olszewski 1996). All other changes were completely marginal corrections due to natural causes, like changes of the course of the streams marking state borders.

In contrast to the external, stable post-1945 borders of the Polish state, the course of internal borders of the administrative units of the first order changed 
many times. In the initial period, it resulted from the fact that the shape of the 1945 Polish state was completely different from its shape from the interwar period. Poland lost to the USSR almost the entire area of six eastern voivodships and fragments of three more, out of the seventeen voivodships existing before the war. At the same time, over 102 thousand sq.km of territories belonging to Germany before the war were incorporated into Poland. This situation required a new outline of the administrative division of the country. The first step, taken already in 1944, was to reactivate the division that existed before the war, after adaptation to the new external borders, as well as to give Łódź the status of a separate unit, which Warsaw had already had before the war. In the years 19451946, the situation in the area taken over from Germany was ordered, which resulted in the creation of 14 voivodships and two cities of separate unit status (Dziki, 2013) (Figure 1).

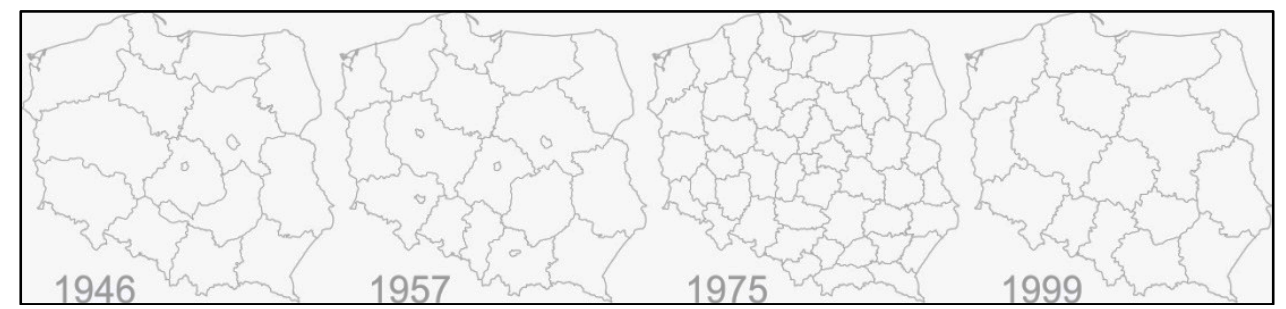

Figure 1. Administrative divisions of Poland in the years 1946-1999 Source: Own elaboration

The division of 1946 lasted for only four years, apart from the small but numerous adjustments to the borders of voivodships that took place in this short period. These corrections were often associated with a change in the affiliation of second-order administrative units, called districts (powiaty), to specific voivodships. In 1950, a reform which resulted in the separation of three new voivodships in the western part of Poland, correction of the borders of five others, change of names of two of them, and the actual liquidation of local selfgovernment was carried out. As a result, the map of the administrative division of the country included 17 voivodships and two separate cities (Figure 1). In 1957, Kraków, Poznań and Wrocław were also granted the status of separate cities, i.e. the number of first-order administrative units increased to 22.

In the period from 1950 to 1974 , further changes were implemented at the lower levels of this division. For example, in 1954, the communes (gminy), i.e. the lowest level units, were replaced by clusters (gromady). As a result, 3,001 small units were replaced by 8,789 tiny units composed in most cases of just a few villages. This reform was, in fact, an introduction to the collectivisation of villages, which was planned to be carried out following the Soviet model. Over the next two decades, several hundred changes took place at the level of clusters, mainly consisting in connecting the neighbouring clusters, which resulted in a reduction in their number to about 4,300 at the beginning of the 1970s. Apart from this significant, systemic, nationwide change, changes were also implemented at the local level, e.g. towns were transformed into clusters, villages into towns, towns 
were merged, clusters were moved between neighbouring districts, new districts were created, which sometimes resulted in minor changes in the borders of voivodships. One of the objectives of these activities was to obliterate the differences between the areas belonging to the different powers that divided Poland in the late $18^{\text {th }}$ century. Dziki (2013, p. 443) accurately summarises these changes as follows: "Most of the above reforms were unsuccessful, unnecessary and brought (...) more problems, ambiguities than positive effects to the inhabitants of the areas covered by them" (translated by the author).

The next significant change in the administrative division of Poland was preceded by the liquidation of clusters and the restoration of the division of rural areas into communes, introduced in 1972. According to the classification proposed by Martí-Henneberg (2005) this was a rationalistic reform. In 1975, the division into first order units was radically changed, with the introduction of 49 new voivodships, divided into 2,327 communes, and districts were eliminated. Theoretically, such a change could stimulate regional development by giving the status of a voivodship city to many medium-sized urban centres. However, regional authorities did not gain additional competencies, and the decentralisation of power did not go hand in hand with a radical reduction in the area of the average voivodship, as this was not the intention of the then authorities and the objectives of the administrative reform (Dziki, 2013). According to official declarations, the plan was to improve administration and economic management and to satisfy social needs better, but the usually cited real reason is the fears of central authorities about the growing importance of voivodship authorities and excessive decentralisation of management. Therefore, a tool to reduce regional authorities' strength was to reduce the size of the area which they controlled.

The last change in the administrative division of Poland so far has been introduced in 1999. At that time 16 large voivodships were established, and a three-tier structure with 373 districts as an intermediate level was introduced. The tasks dedicated to voivodships were divided between the voivod, who is the representative of the central authority in the field, and the marshal of the voivodship, who is the representative of the local government. This structure clearly refers to the one existing before the 1975 reform, both because of the three-stage division and because of the similar number of voivodships. As of January $1^{\text {st }}$, 2020, the number of voivodships has not changed; Poland has 380 districts and 2,477 communes.

Each change in the administrative division of Poland, including the latest one, was connected with turbulent discussions concerning the future shape of the organisation of the country' territorial system. Jałowiecki (1996b) in the first years after the political changes that started in Poland in 1989, identified as many as 26 concepts of a new territorial division of the country. Among them there were concepts assuming the liquidation of the existing voivodships and the introduction of only a few new, strong units, equipped with a relatively wide range of competences, bringing Poland closer to the concept of a federal state. At that point in time, the number of future voivodships proposed was at $5,6,7$ or 8 . The then Polish government pushed for the proposal of 12 voivodships, but this 
proposal, however, fell under strong pressure from the regional authorities of four cities which vehemently opposed them losing the rank of voivodship cities. This is how Kujawsko-Pomorskie, Lubuskie, Opolskie and Świętokrzyskie voivodships appeared on the map. Next, a 17 voivodships structure was proposed, and this proposal was a faithful return to the division from before 1975, and a few proposals to merge the existing voivodships into groups (25 to 35 new units), to remove only the weakest units (40) and finally to keep the status quo of 49 voivodships.

The introduction of the reform of the administrative division of Poland did not close the discussion on this division - it has even intensified it. Miszczuk (2003) identified as many as 54 proposals for further changes put forward by scientific and planning circles, politicians and local governments. The most widely publicised were the proposals to create Staropolskie (including Świętokrzyskie and the northern part of Ślaskie voivodships) and Środkowopolskie (from the eastern part of Wielkopolskie and fragments of other voivodships) (Figure 2).

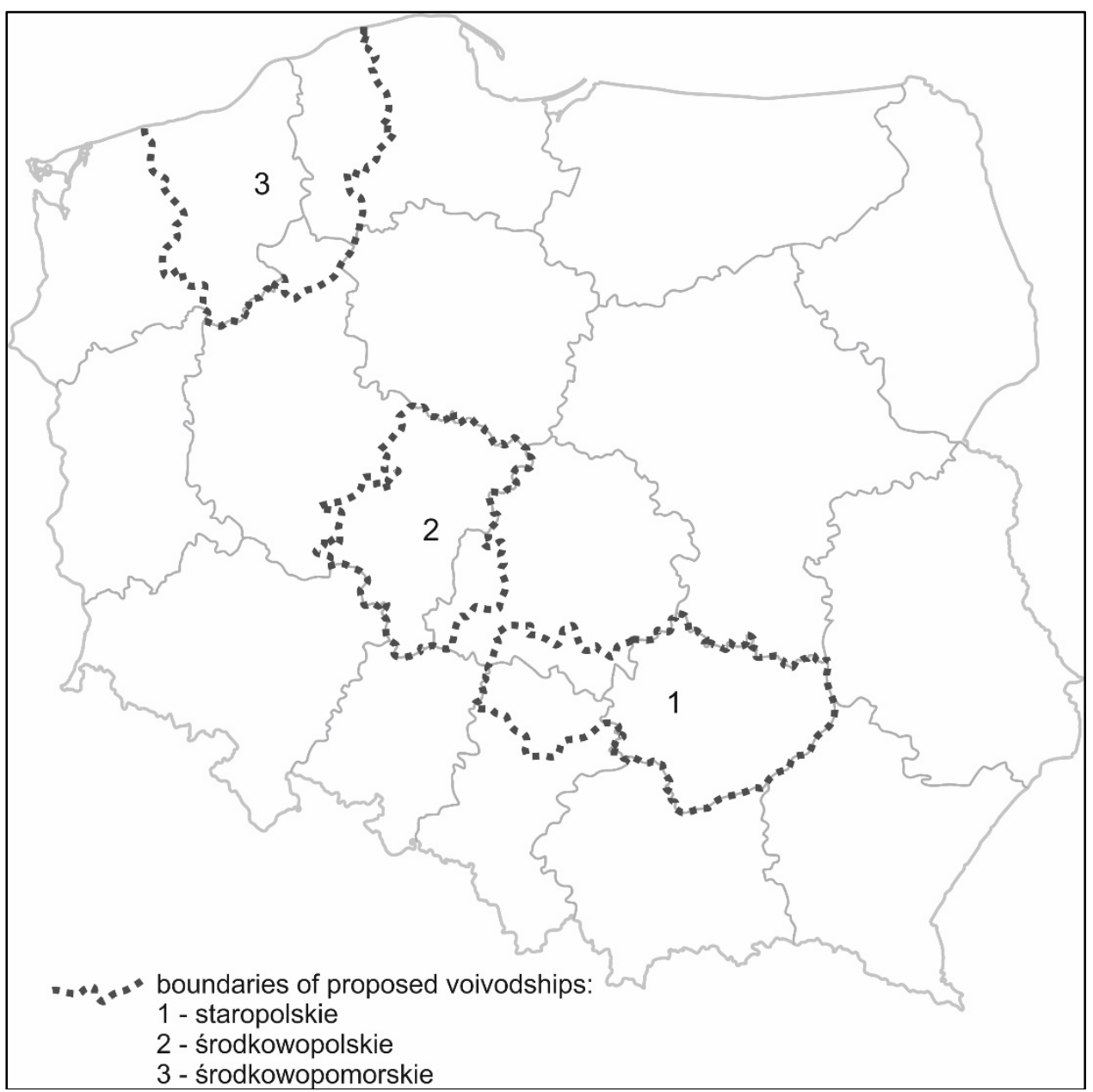

Figure 2. Proposals of changes in the administrative division of Poland after 1999 Source: Own elaboration 
However, the loudest was the proposal to create a Central Pomeranian Voivodship, which would cover the borderland parts of the Pomorskie and Zachodniopomorskie, with Koszalin and Słupsk as two capital cities. The arguments used in the public debate to support the promoted project were often not of a substantive nature and did not refer to existing economic or social ties, but brought arguments of a political or emotional nature. This was most clearly visible in the debate on yet another proposed creation, namely Częstochowskie Voivodship. The most original arguments were the ones verbalised by one of the Catholic publicists:

\footnotetext{
"(...) during the last administrative reform Częstochowa - the 12th largest city in Poland - was also hurt by depriving it of the dignity of a voivodship city. (...) Czestochowa is a city of great importance for Poland, but also for Poles all over the world. It is our spiritual capital (...) The history of Czestochowa is a beautiful chapter in the history of Poland. It is mainly over 600 years of Jasna Góra's existence, and with it the occurrence of events as important for our country as the victorious defence of the monastery during the Swedish Deluge, whose 350th anniversary we celebrated last year (...)" (Skubiś, 2006).
}

Both the emotional argumentation used by many supporters of the introduction of subsequent changes, the need to keep electoral promises, or the huge multiplicity of concepts of a new administrative division in itself testify to the lack of a stabilised territorial division of Poland shaped throughout history. This allows us to conclude that there are no objective regions in Poland; otherwise, the number of submitted reform proposals would probably be much smaller; similarly, their differentiation would not be so significant. In this context Gorzelak (1993) accurately noticed that the discussion about the Polish state's structure is little substantive and strongly politicised - this astringent remark is still valid today. As Miszczuk (2003) further notes, the last reform did not implement any of the scientifically developed concepts. It was the result of a political game played by political parties, and political regionalisation used geographical regionalisation as an instrument, with a lack of respect for the basic principles of the latter. Out of the 54 reform mentioned above, only four proposals contained the finally selected variant of sixteen voivodships, although none of them provided for such a course of borders as was later introduced in 1999 (Miszczuk, 2003). Although Zawadzka (1993) is right in claiming that there are no regions in which all spatial patterns overlap perfectly, and all the criteria for regionalisation are met, Wojtkowiak (2000, p. 35) wrote that "...planners treat Polish lands as if they were a 'minced cutlet', susceptible to both any cuts and mergers".

\section{Results and discussions}

How, then, can a country be divided up administratively in order to make the division satisfactory? These considerations should start with the identification of priorities. The majority of authors believe that the absolute priority should be the 
socio-economic criterion, taking into account the contemporary settlement network and functional links and not cutting through natural social ties (Jałowiecki, 1996a).

Among the numerous suggested criteria for a correct regionalisation, Kowalczyk (1993) points to the need to ensure the proper rank of big cities, postulates taking into account changes like the state border (e.g. its permeability level), suggests to give up efforts to unify the size of regions and to take into account the need for regions to establish cross-border relations. It is worth noting, however, that in numerous analyses related to the administrative division of Poland, although usually outside the mainstream networks, there are proposals to take into account the historical course of administrative borders. Kowalczyk (1993) notes that four proposals for administrative reform, developed before 1999 out of 22 analysed by the Team for the Concept of Changes in the Territorial Organization of the State, established in 1991, were based on historical and cultural regions, and the authors of this analysis directly postulate that regionalisation should refer to historical divisions. More than that, Miszczuk (2003) notes that the historical factor, although not strongly emphasised, played a significant role in the creation of the current administrative division. Thus, historical regions understood as spatial units, which owe their distinctness to their historical otherness (Szul, 1993), could constitute one of the bases for the creation of the administrative division.

Although the dogmatic adherence to the course of old borders in the creation of the current administrative division is pointless, it seems equally irrational to completely omit the course of these borders in the deliberations on the new administrative division. The formerly existing administrative boundaries should be treated not so much as a somewhat mechanical reference point in deliberations, but as information about the intra-regional relationships that have arisen within such entities during the time they existed. If one assumes that the existence's lengths of such units is one of the factors influencing the strength of the intra-regional connections that have been created, and thus also one of the possible measures of its strength, then one can conclude that the influence of the region's permanence on its existence as an objective entity is significant.

The durability of the region as the necessary criterion of the territorial organisation of the state is a postulate rarely raised in the specialised literature. In the light of the previous considerations, it seems, however, that this criterion is predisposed to take precedence over other regionalisation criteria. The high frequency of changes in the administrative division means that the state is permanently disorganised. Additional negative consequences of introducing changes in the administrative division are the necessity of incurring significant expenditures on subsequent reforms, as well as several unfavourable phenomena in the social sphere, e.g. breaking tradition, disintegrating social ties, or atomisation of local and regional communities (Alexandrowicz, 1993). The durability of administrative division translates into political stabilisation and creation of the beginnings of regional identity. Incidentally, one of the objectives of the 1999 reform was to rebuild it (Miszczuk, 2003). It is also worth noting that 
the long-established administrative region shapes new regional structures, connections and interdependencies, thus with time an objective region, being a subject of cognition, is created step-by-step (Chojnicki \& Czyż, 1993). If it was possible to create regions that would be research tools, tools for action and objects of cognition at a time, one could talk about optimal regionalisation and the creation of objective regions. In order for a region to be stable, some conditions must be met. The following three conditions are necessary, but not sufficient to create stable regions. Firstly, there should be a clear link between the region within its administrative boundaries and the political, social, economic, physical and geographical reality of the region. Secondly, the inhabitants of the region should identify themselves with their place of residence. Thirdly, a few generations should pass so the region could consolidate itself within certain limits.

Even a cursory comparison of the three conditions mentioned above with the situation in Poland allows us to conclude that the contemporary administrative units of the first order are not stable. The networks of intra-regional connections created over the years were regularly disrupted, with the most striking example being the 1975 reform, although the reform plans also proposed in the interwar period did not show respect for the ties formed in the historical processes (Wendt, 2001). Regional identification in Poland is weak, especially in the younger generation. National and local identity is stronger, and according to many studies, even European identity is stronger (Szul, 1993; Jałowiecki, 1996a; Firlit 2002).

Although it is not possible to unambiguously determine the time necessary for the formation of the region, past examples suggest that it takes at least several generations to be able to speak of the formation of a regional identity. This is clearly visible in the so-called western lands, i.e. in the areas located in the western and northern parts of present-day Poland, which were previously owned for several hundred years by other geopolitical units (i.a. Prussia, the German Empire). They were settled after World War II by refugees and people displaced from the pre-war eastern part of Poland. Despite over 70 years since the end of warfare - which means three generations - a regional identity has not yet been created there (Szul, 1993). The main cause for this, however, should be borne not only by time but also by the process of making continuous changes to the regions' borders. Each significant change in the administrative division means breaking the regional ties that had begun to form, undermining the slowly emerging regional identity.

On the other hand, many examples are justifying the conclusion that it possible to maintain the long-term durability of regions. A well-known example is the Swiss Confederation (Martí-Henneberg, 2005); another example is the federal Germany, where after the end of World War II only one correction was made at the highest level of administrative units, consisting in merging in 1952 of two Länder - Baden and Württemberg into one organism. Also, in unitary countries, despite entirely different state paradigm, it is possible to maintain a stable administrative division. An example is France, where the administrative division at the departmental level has hardly changed since Napoleonic times if one ignores the multiple divisions into parts and the reintegration of Corsica, and the 
changes resulting from the changes of state borders. The only significant change at this level, which constituted the administrative foundation of France, was the partial division of the two pre-existing departments into parts in 1968.

Durable regions are, therefore, regions based on borders that have been in the same place for a long time. Such borders are visible not only on administrative maps but also in the socio-economic reality. Areas embraced by former borders are often referred to as historical regions. If the former administrative border, or the former state border, does not exist today, but its lengthy existence has created differences in social or economic reality on both sides, then we are talking about a relict border. In Poland, a significant part of the former state borders between Poland and the German state, as well as part of the partition borders are of the character of relict borders. Poland was divided among the partitioners - tsarist Russia, Prussia and Austria-Hungary - for 146 years, including 123 years when it completely disappeared from the political map of Europe. This period was not long enough to deprive Poles of the ability to communicate in their native language, but at the same time, it enabled the creation of different communities on both sides of the border. Now these populations they are characterised by entirely different social and economic behaviours, as well as different perceptions of reality. The boundary between the Kingdom of Poland, which was fully subordinated to the Russian Empire, established in 1815, and Prussia, is exceptionally strong. This is also visible in the results of almost all the successive parliamentary and presidential elections, in which the inhabitants of areas formerly belonging to the German state choose left-wing and liberal parties, and the inhabitants of the Russian and Austrian partitions choose conservative rightwing and folk parties.

Another example is the age structure of the society, which is much older in eastern Poland than elsewhere (Kowalski, 2018). Going deeper into the past, Wojtkowiak (2000) claims that the division into geographical-historical regions (natural districts), formed based on early medieval supra-tribal relationships and shaped in centuries-old historical processes, is durable. Regardless of the extent to which such a far-reaching statement is correct, it can be concluded that the long existence of certain political or administrative divisions in space has a significant impact on today's socio-economic processes and is a factor co-responsible for shaping the diversity of communities living in areas located on both sides of the border. Thus, the prolonged existence of a border is a causal factor in the creation of objective regions. Accordingly, administrative regions could successfully - and perhaps even should - be created based on the borders of historical regions.

Although it is difficult to find research works that openly present such a thesis, many authors have noticed in passing how important historical conditions are for contemporary administrative borders (Martí-Henneberg, 2005). Many also claim, although detailed spatial analyses do not support this, that the convergence between the course of old borders in their general outline and the course of contemporary borders is very significant. Piskozub (1987) notes that the foundations of the present structure existed for 1,000 years, except for the partition period. Gorzelak (1993) indicates that the regional division of 
contemporary Poland refers to the first divisions in the $11^{\text {th }}$ century. Wojtkowiak (2000) notes that administrative borders in the interwar period clearly imitated the borders of the partitions. In turn, Kowalczyk (1993) claims that the plans of administrative reform in the interwar period mostly referred to pre-partition historical conditions, although they were not implemented. Finally, Miszczuk (2003) is convinced that the historical factor, although not strongly emphasised, played a role in shaping the current administrative division. It is also worth noting that regional names from the Piast era, the era of the first dynasty of Polish kings ruling the country at least from 966 to 1370, are still commonly used in the common language. In the early days of Piasts, i.e. in the $9^{\text {th }}$ and $11^{\text {th }}$ centuries, names such as Mazowsze, Wielkopolska, Małopolska, Śląsk and others were used.

In the light of all the above considerations, the thesis that the historical region, understood as an administrative unit of the first order of the past, gains full right to co-determine the current shape of the territorial division of the country. The consequence of adopting a historical region as a basis for creating a contemporary administrative division is that it is necessary to choose one of the administrative divisions of the past as a reference point. In this paper, due to its objectives, the direction of the analysis will be reversed. The borders of contemporary voivodships will be confronted with the borders of historical regions in order to determine to what extent they converge with each other. However, even in such a situation, the question of which borders from the past should be confronted with contemporary borders remains difficult to resolve objectively. Some of them existed for only a few years only, and others survived without any significant changes several dozen or even hundreds of years. Some remain in the social consciousness to this day; others are known only to specialists. Moreover, the number of historical regions in Poland in particular historical periods is subject to constant disputes, so the delimitation of borders is even more controversial. This problem gradually deepens as we go back in time to become a pivotal obstacle to a detailed analysis in the early Piast era. As an example, the subject of endless discussions among historians is still the number and borders of districts from the time of the beginning of feudal fragmentation in the $12^{\text {th }}$ century.

It is also worth noting that the borders passing in a given place, e.g. 50 years in the $10^{\text {th }}$ century and the $20^{\text {th }}$ century do not have the same influence on today's social and economic reality. The older borders probably shape to a lesser extent today's socio-economic processes than the younger ones, so the latter should be given a higher rank in the analysis. On the other hand, the activity of weighting certain borders is extremely non-objective, exposing the final results of the analysis to subjectivism. In this context, and also because Jałowiecki (1996a) rightly stated that the current diversity of many economic processes in Poland, such as settlement or agrarian diversity, has pre-partition roots - therefore is over 200 years old - it was assumed that no borders would be assigned weights modifying their meaning depending on any variables. However, the higher importance of more contemporary borders will be emphasised through their numerical over-representation in further analyses. Finally, 11 historical periods represented by 21 moments in time were selected (Figure 4). 
For each of the selected years, a map of the course of state borders and borders of administrative units of the first order was made. Then all borders were plotted on one map (Figure 3) in order to finally compare their location with the administrative borders of contemporary voivodships. The borders of historical regions were established based on the most reliable available sources of on this subject, i.e. historical atlases and, despite numerous doubts, further analysis was based on the maps contained therein. In the analysis, maps from six geographical and historical atlases were used, including three published in contemporary Poland, one published in contemporary Germany and two published at the beginning of the 20th century in Germany and Austria-Hungary.

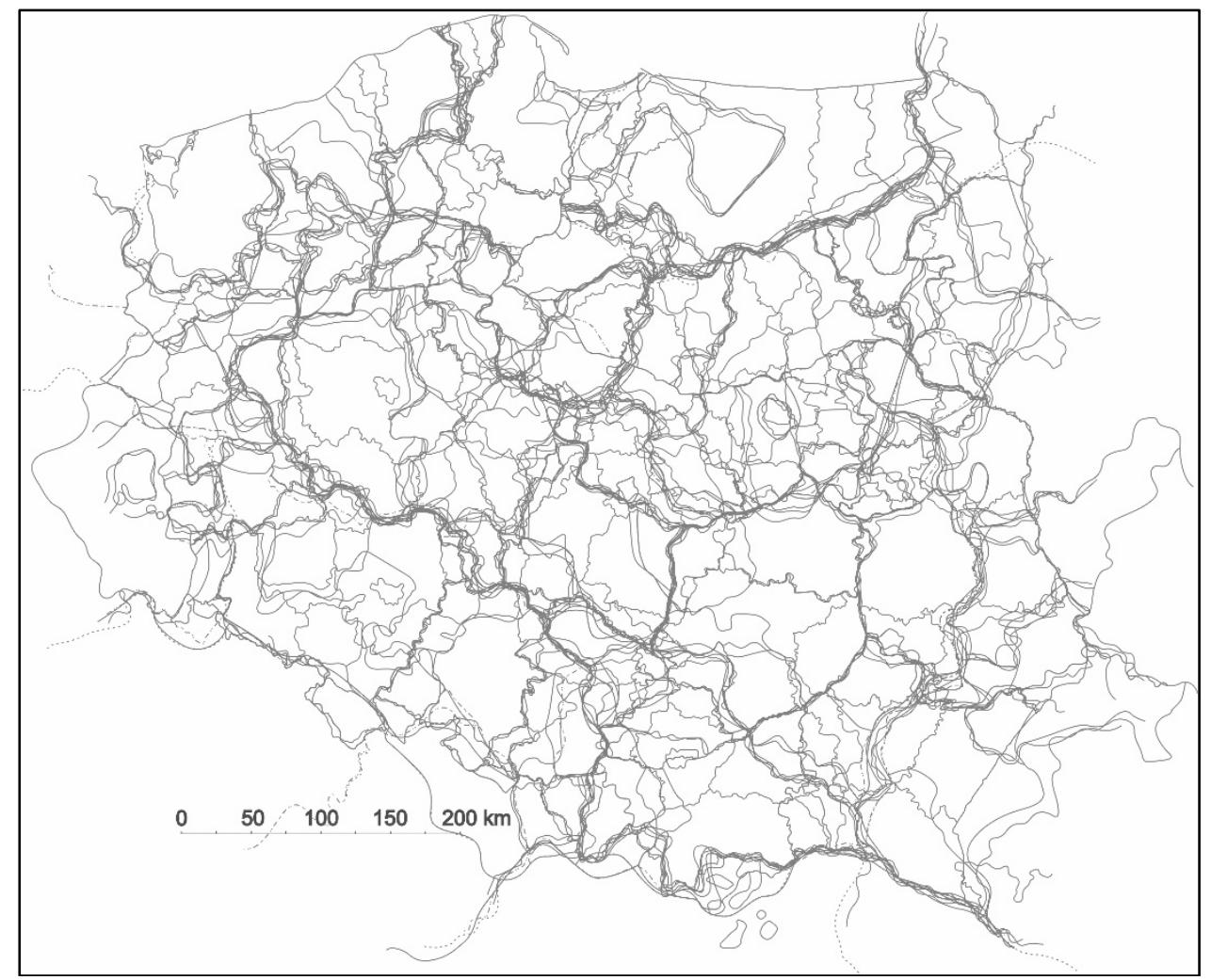

Figure 3. Political and administrative borders of Poland in the period 990-1993

Source: study prepared by Kamila Łucjan based on the author's guidelines and the following sources: Atlas historyczny Polski, 1996, red. W.Czapliński, T.Ładogórski, PPWK, WarszawaWrocław; Atlas historyczny do 1815 roku, 2004, red. J.Tazbir, S.Kryciński, Wydawnictwo Demart; Atlas historyczny 1815-1939, 2000, red. J.Tazbir, S.Kryciński, Wydawnictwo Demart; Kleiner Atlas zur deutschen Territorial Geschichte, 1991, B.Jähnig, L.Biewer, Kulturstiftung der deutschen Vertriebenen; Diercke Schul-Atlas 1900, Braunschweig. George Westermann; Andrees Neuer Allgemeiner und Österreichisch-Ungarischer Handatlas, 1904, A.Scobel, Verlag von Moritz Perles, Wien.

The preliminary, cursory analysis of the cartographic material presented here allows us to conclude that there is a significant convergence of the modern borders with the former ones. In order to verify the correctness of these 
conclusions, a series of maps were made on which the fragments of the borders of contemporary voivodships that also existed in the past were marked (Figure 4). The last map is a result of the overlapping of all the previous maps. It is a great surprise that the vast majority of the borders of today's voivodships find their equivalents in the past. It should be noted, however, that maps on Figure 4 show in an identical way all fragments of contemporary borders that existed in the past, no matter how long they used to exist. In order to distinguish which of the drawn borders is durable and long-lasting and which was short-lived, another map was made, where the line thickness and the colour intensity signals the level of durability of the border (Figure 5).

Figure 5 shows that among the borders of modern voivodships, some existed for many historical periods, there are also contemporary borders which hardly find any reference in the position of the borders of historical regions. A detailed analysis of the durability of borders in comparison with their length showed that $22.5 \%$ of the borders existed for at least eight historical periods, further $12.8 \%$ for 6-7 periods, further $20.4 \%$ for $4-5$ periods. The borders of high and medium durability constitute $55.7 \%$ of the total length of all the voivodship borders. Borders of low durability, existing for no more than three historical periods, constitute $34.9 \%$ of the total length of borders, whereas borders which never existed in the past make out only $9.4 \%$.

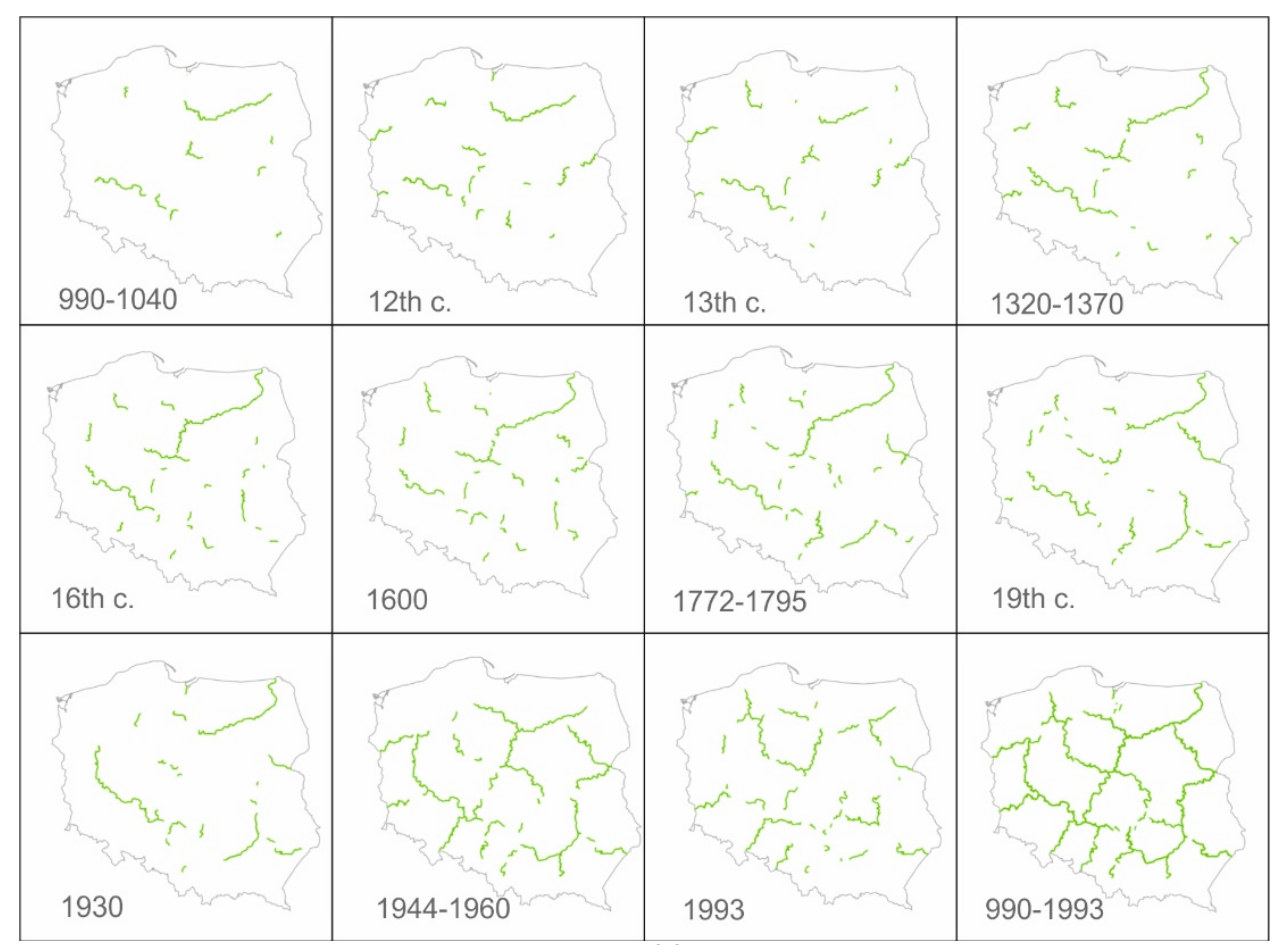

Figure 4. Relationship between the location of former and modern administrative borders Source: Own elaboration 
Therefore, it may be stated that more than half of the currently existing administrative borders are borders that have had a significant or very significant impact on the differentiation of social and economic processes on both sides of the border, and consequently also on the present situation in voivodships separated from each other by these borders.

In the context of earlier considerations, it can be concluded that some of the borders of contemporary voivodships were, in passing, correctly drawn within the framework of the recent reform of the administrative division of Poland. Their course preserves the otherness of the neighbouring areas and strengthens the links within each of them individually, allowing for the continuation of the process of shaping objective regions. In the second case, when borders existed for a short time or did not exist at all in the past, they should be considered as artificial, completely detached from the reality shaped by historical processes. Once again, they tear apart the socio-economic fabric of the regions they have divided into parts and prevent the creation of objective regions.

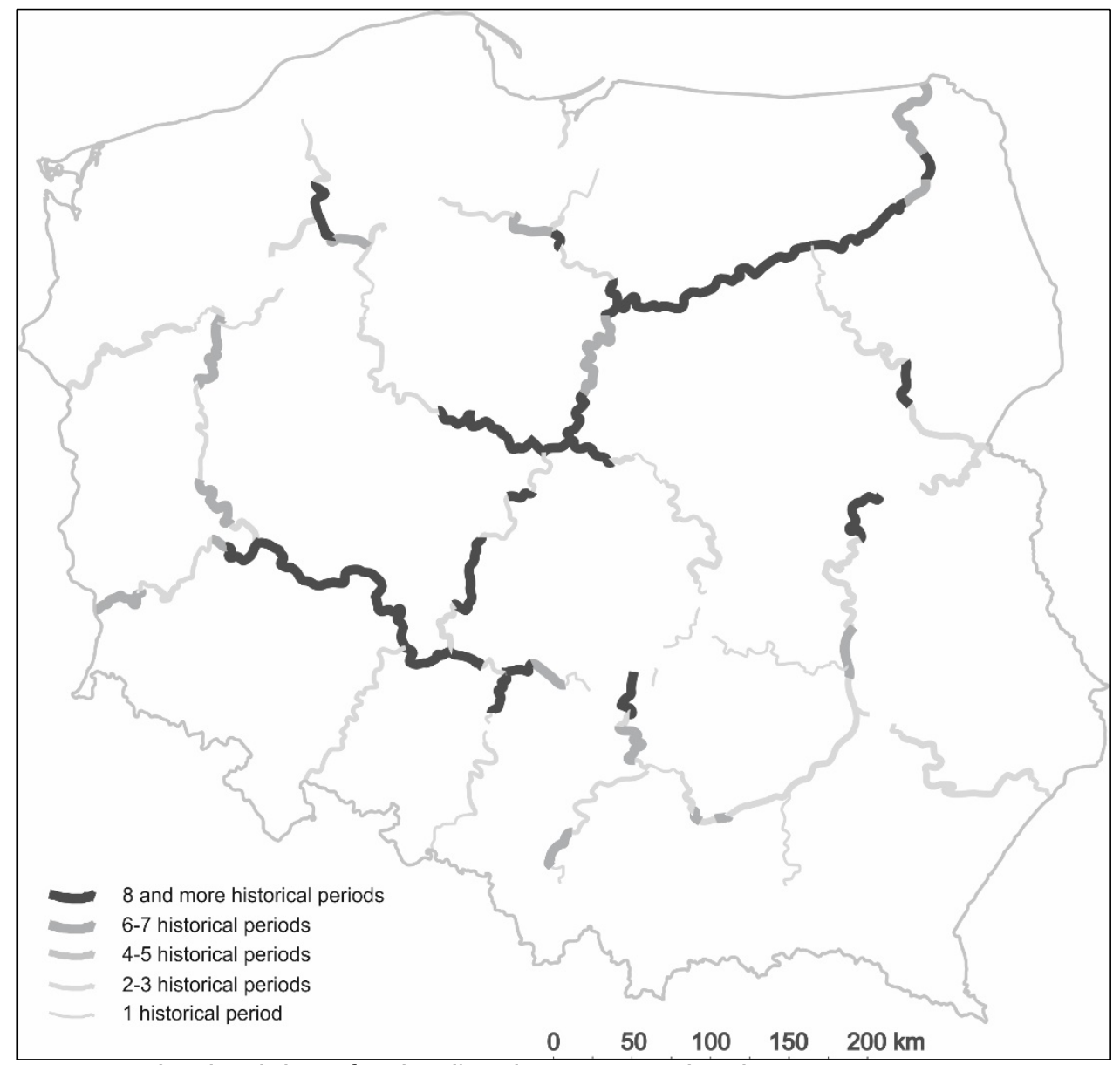

Figure 5. The durability of Poland's administrative borders Source: Own elaboration 


\section{Methodological remarks}

The graphical analysis of the borders presented above, although carried out with great care and accuracy, cannot aspire to be a fully objective and flawless reflection of reality. Obviously, this limits the possibility of unambiguous interpretation of the maps. Although every effort was made to maximise the objectivity of the conducted research, the selection of analysis periods was subjective, and the introduction of new periods of time to the analysis or elimination of some of those already taken into account would undoubtedly introduce some changes in the final image. The high frequency of changes in some boundaries was an additional difficulty in the selection of the periods analysed.

The analysis was based on cartographic sources, whose reliability depends directly on the knowledge of historians and cartographers about the course of borders in the past. This knowledge is neither complete nor precise, especially concerning the borders from the oldest historical periods. The level of accuracy of maps made centuries ago was low, so the borders visible in modern atlases should be treated as approximations of the actual course of the old borders, and not as their exact course. Available historical sources concerning the property status of individual rulers are of course helpful in determining the course of borders, but the low density of settlement in the distant past makes it impossible to precisely guide the border on a map based on these descriptions.

It should also be noted that the oldest borders were rarely linear in today's understanding of this term. They usually had a zonal character, and the actual width of the border zone is not only unknown but also was different for different borders in a given period and changed with time. This reservation applies both to national and regional borders (Rykiel, 2006). The source materials used in the paper, i.e. geographical and historical atlases, do not present, however, the zonal course of the borders, but rather the linear course. For our analysis, it means the necessity to accept a certain level of discrepancy in the location of borders marked on one map. The difference of a few, or sometimes of several kilometres, may mean that in practice it was the same line.

In some cases, the level of uncertainty regarding the actual course of the borders is even higher. As already mentioned, the number of districts into which Poland was divided in the $12^{\text {th }}$ century has not been univocally stated, and the course of their borders is even less well known. The closer to the present day we analyse, the higher the level of certainty regarding the actual course of the borders of the regions becomes. Moreover, the importance of borders from a thousand years ago for today's regions cannot be directly compared with the importance of the borders from recent historical periods; hence the decision taken to over-represent the youngest historical periods in the analysis allowed for partial elimination of the errors resulting from both factors presented herein.

Another problem, regarding both state and administrative borders, is their frequent variability. This is true not only for distant historical periods but also for contemporary Poland. The need to select specific dates for which the analysis is performed means that the analysis does not cover full variability, but a certain 
portion of it, the selection of which influences the results obtained in a fundamental way. Awareness of this limitation influenced the decision to choose dates that reflect the most characteristic boundaries of a given period.

The next identified problem is a different level of influence, and therefore the importance of state and regional borders for the social and economic situation of the separated units. To a certain extent, the level of importance of the borders of historical regions in various historical periods is also incomparable. This results from the different level of permeability of borders, from the changing scope of competences of regional authorities, as well as from the number of units into which Poland was divided in relation to its area at that moment. The higher the number of small units, the smaller their impact on the consolidation of social and economic diversity should be expected.

It is also worth noting that the source cartographic materials were maps in several different cartographic representations and different scales (from 1:3M to 1:6M), which entailed a different degree of their generalisation and consequently forced the assumption of tolerance for discrepancies between the course of borderlines from different periods. For maps depicting the situation from the $10^{\text {th }}$ to the $17^{\text {th }}$ century a tolerance of up to 10 kilometers was assumed, which meant a tolerance of less than $2 \mathrm{~mm}$. on the map, and for maps depicting younger historical periods - up to 5 kilometers ( $1 \mathrm{~mm}$. on the map).

\section{Conclusions}

All the above limitations force us to conclude the analysis with caution. It seems, however, that the adoption of the presented solutions, which to some extent mitigate the negative impact of the limitations on the value and accuracy of the final image, makes it possible to state that relatively few of the contemporary borders of Polish voivodships are borders fixed by history in a very significant way. On the other hand, many sections of the contemporary borders also existed in the past for a longer or shorter period of time.

The aim of this paper was to analyse the course of borders of historical regions in Poland, understood as administrative units of the first order, in the period from the beginning of Polish statehood at the end of the $10^{\text {th }}$ century to the $21^{\text {st }}$. In the context of the thesis that one of the critical features of a good administrative division of the state should be the durability of the units into which it is divided, the former course of the borders of these units was juxtaposed with the present one. As expected, some of the current borders of contemporary voivodships are borders that have never or almost never existed in the past, but surprisingly, there are many borders that have a strong historical basis. For this reason, the influence of the latter on the differentiation of social and economic processes on both sides of the border, and thus on the deepening of regional differences, should be considered as significant.

In the period preceding the reform of Poland's territorial organisation introduced in 1999, there were many opinions about the far too large number of 
voivodships and the need to reduce it. Similar voices are also frequent today, although scientists and politicians sometimes make the opposite declarations about the need to increase the number of voivodships and to grant the status of voivodship cities to other centres, including Koszalin, Słupsk, Częstochowa and Kalisz. In the context of the considerations presented above, it seems justified to state that frequent changes in the administrative division of the country do not serve anyone and anything well. As a rule, it brings immediate political benefits to activists who try to raise their political capital.

Since there is no universal, best administrative division, the efforts to introduce further changes to this division should be discontinued. The best solution is to assume that the current administrative division will be the last one. If necessary, it is possible to make changes of a corrective nature, in line with the functionalist model (Martí-Henneberg, 2005), or changes at lower levels of administration. Maintaining the current division of power for a long time may lead to political stabilisation and the formation of objective regions. The high convergence of administrative borders in the period 1946-1974 and after 1999 gives a chance to maintain this division in the social awareness, which is a necessary condition for the creation of regional identity and objective regions.

\section{References}

Alexandrowicz, S. (1993), "Różne pojęcia historii regionalnej i możliwości jej uprawiania", in K. Handke (ed.), Region, regionalizm. Pojęcia i rzeczywistość, p. 3748, Slawistyczny Ośrodek Wydawniczy, Warszawa.

Chojnicki, Z. and Czyż, T. (1993), "Region i regionalizacja w geografii", in K. Handke (ed.), Region, regionalizm. Pojęcia i rzeczywistość, p. 13-36, Slawistyczny Ośrodek Wydawniczy, Warszawa.

Cox, K.R., Low, M. and Robinson, J. (eds) (2008), The SAGE Handbook of Political Geography, Sage Publications, Los Angeles, London, New Delhi, Singapore.

Czubiński, A. and Olszewski, W. (1996), Historia powszechna 1939-1994, Poznań.

Dumolard, P. (1980), "Le concept de la region: ambiquiutes, paradoxes ou contradictions? Reims, 41-42, 21-32", after: Chojnicki, Z. and Czyż, T. (1993), "Region i regionalizacja w geografii", in K. Handke (ed.), Region, regionalizm. Pojęcia i rzeczywistość, p. 13-36, Slawistyczny Ośrodek Wydawniczy, Warszawa.

Dziewoński, K. (1967), "Teoria regionu ekonomicznego", Przeglad Geograficzny, vol. 39, no. 1, p. 33-50.

Dziki, T. (2013), "Podziały administracyjne Polski w latach 1944-1998. Z badań nad ustrojem ziem polskich w XIX i XX w", Studia Gdańskie. Wizje i rzeczywistość, vol. X, p. 433-450.

Elazar, D.J. (1999), "Political science, geography, and the spatial dimension of politics", Political Geography Oxford, vol. 18, no. 8, p. 875-886.

Firlit, E. (2002), "Poczucie tożsamości narodowej Polaków w świetle badań empirycznych", in P. Gulczyński and B. Loba (eds.), Tożsamość narodowa Polaków w przyszłej Europie, p. 44-52, Warszawa. 
Gorzelak, G. (1993), "Regionalizm i regionalizacja w Polsce na tle europejskim". in G. Gorzelak and B. Jałowiecki (eds.), Czy Polska będzie państwem regionalnym? Studia Regionalne i Lokalne, p. 45-70, Warszawa.

Jałowiecki, B. (1996a), "Oblicza polskich regionów (wstęp)", Studia Regionalne $i$ Lokalne, p. 5-18, Warszawa.

Jałowiecki, B. (1996b), "Przestrzeń historyczna, regionalizm, regionalizacja", in B. Jałowiecki (ed.), Oblicza polskich regionów, Studia Regionalne i Lokalne, p. 19-88, Warszawa.

Janicki, W. and Łucjan, K. (2009), "Przebieg granic regionów historycznych, a współczesne granice administracyjne w Polsce", in M. Kulesza (ed.), Geografia historyczna jako determinanta rozwoju nauk humanistycznych, PWSZ im. Witelona w Legnicy, p. 109-117.

Jones, M., Jones, R. and Woods, M. (2004), An Introduction to Political Geography: Space, Place and Politics, Routledge, New York.

Kolossov, V. (2005), "Border studies: Changing perspectives and theoretical approaches", Geopolitics, vol. 10, no. 4, p. 606-632.

Kowalczyk, A. (1993), "Dotychczasowe doświadczenia i aktualny stan prac badawczych nad reformą podziału Polski na regiony", in G. Gorzelak and B. Jałowiecki (eds.), Czy Polska będzie państwem regionalnym? Studia Regionalne $i$ Lokalne, Warszawa.

Kowalski, M. (2018), "Co ukształtowało regionalne zróżnicowania zachowań wyborczych?", in J. Szomburg and M. Wandałowski (eds.), Polskie etosy regionalne $i$ ich znaczenie z perspektywy ogólnonarodowej, no. 82, p. 59-65, Wolność i Solidarność, Instytut Badań nad Gospodarką Rynkową, Gdańsk.

Lunden, T. (2004), On the boundary. About humans at the end of the territory. Södertörns högskola, Huddinge.

Martí-Henneberg, J. (2005), "The Map of Europe: Continuity and Change in Administrative Boundaries (1850-2000)", Geopolitics, vol. 10, no. 4, p. 791-815.

Minghi, J. (1963), "Boundary studies in political geography", Annals of the Association of American Geographers, vol. 53, p. 407-428.

Miszczuk, A. (2003), Regionalizacja administracyjna III Rzeczypospolitej. Koncepcje teoretyczne a rzeczywistość, Lublin.

Piskozub, A. (1987), Dziedzictwo polskiej przestrzeni. Geograficzno-historyczne podstawy struktur przestrzennych ziem polskich, Wrocław.

Rykiel, Z. (2006), Podstawy geografii politycznej, PWE, Warszawa.

Skubiś I. (2007), Częstochowa - powiat czy województwo. 11/2006, 12 august 2019, shorturl.at/eBCS3.

Sng, T.H., Chiaa, P.Z., Fen,g C.C. and Wang, Y.C (2018), "Are China's provincial boundaries misaligned?", Applied Geography, no. 98, p. 52-65.

Sobczyński, M. (1984), "Niezmienność dawnych granic politycznych na obszarze Polski", Acta Universitatis Lodziensis, Folia Geographica, no. 3, p. 119-137.

Szul, R. (1993), "Some problems of regionalisms in contemporary Europe with special reference to Eastern Europe", in G. Gorzelak and B. Jałowiecki (eds.), Regional question in Europe. Question regionale en Europe, pp. 343-368, Warszawa. 
Taylor, P.J. and Flint, C. (2000), Political Geography, World-Economy, Nation-State and Locality. $4^{\text {th }}$ ed., Prentice Hall, Harlow.

Wendt, J. (2001), Geografia wtadzy w Polsce, Gdańsk.

Wojtkowiak, S. (2000), Jak przez wieki administracyjnie dzielono $i$ jak ostatnio podzieliliśmy terytorium Polski, Łódź.

Yoder, J.A. (2003), "Decentralisation and Regionalisation after Communism: Administrative and Territorial Reform in Poland and the Czech Republic", Europe-Asia Studies, vol. 55, no. 2, p. 263-286.

Zawadzka, B. (1993), Województwo i region. Wnioski z doświadczeń francuskich, Warszawa. 